\title{
High Resolution Biostratigraphy of the K/T Boundary in the Higran Section, Shaqlawa Area, Northern Iraq
}

\author{
Rund A. Hammoudi \\ Department of Biology \\ College of Science \\ University of Duhok
}

(Received 22/12/2009, Accepted 24/6/2010)

\begin{abstract}
The Higran section in northern Iraq exposes the contact between two widely recognized formations. They are the Shiranish and Kolosh Formations, considered to be of Cretaceous (Campanian-Maastrichtian) and Tertiary (Paleocene-Eocene) ages respectively. Samples were taken from above and below the physical contact between the two formations at 5 to $7 \mathrm{~cm}$ apart. Planktonic foraminiferal biostratigraphic analysis of the Higran section indicates that the Cretaceous /Tertiary boundary in this section is hitherto the most complete and expanded section in Iraq up to date. Quantitative high resolution foraminiferal biostratigraphic analysis has shown that a major biotic change in the planktonic foraminifera occurred during the end of the Cretaceous to the beginning of the Tertiary. The Maastrichtian Gansserina gansseri and the Abathomphalus mayaroensis Zones were recognized. The Abathomphalus mayaroensis Zone was subdivided into three subzones they are: Racemiguembelina fructicosa Subzone, Pseudoguembelina hariaensis Subzone and part of Pseudoguembelina palpebra Subzone. The defined Tertiary zones are: Guembelitria cretacea Zone, Parvularugoglobigerina eugubina Zone, Parasubbotina pseudobulloides Zone and part of the Parasubbotina varianta Zone. This study has established the absence of the Plummerita hantkeninoides Zone within the Cretaceous succession indicating a hiatus (Diastem) between the Cretaceous and Tertiary successions. The planktonic to benthonic ratio of the Shiranish Formation across the K/T boundary shows the role of the outer shelf to upper slope environments well above and below the $\mathrm{K} / \mathrm{T}$ boundary in the section, hence it is characterized by lithologic continuity above and below the missing interval. The planktonic foraminiferal extinction in the Higran section occurred gradually and over relatively long period. Seventeen species $(40.5 \%$ of the Cretaceous species) became extinct in the Late Maastrichtian before the first appearance of the Tertiary species, whereas nineteen species $(45.2 \%)$ disappeared
\end{abstract}


exactly with the hiatus that defines the K/T boundary in the studied section. Most of the extinct forms are large, complex, tropical and subtropical. Nevertheless, five species of the small cosmopolitan generalists with simple morphologies $(14.3 \%$ of the Cretaceous species) survived the K/T boundary and the drastic change in the ecosystem. They did however become extinct in the Early Danian. The fine biostratigraphic analysis also revealed that the $\mathrm{K} / \mathrm{T}$ boundary is located in the same lithology of blue marls within the Shiranish Formation, rather than at the contact between the Shiranish and Kolosh formations.This study has shown that the wellknown Shiranish Formation conventionally taken to be of Cretaceous age, actually extends into the Paleocene in the Higran section. In essence, the turnover of the Cretaceous foraminifera which defines the end of the Cretaceous is located one meter below the physical contact between the Shiranish and the Kolosh formations.

الطباقية الحياتية الدقيقة للحد الفاصل بين العصر الكريتاسي والتيرشري في مقطع هجران،

\section{منطقة شقلاوة، شمال العراق}

$$
\text { قند علي حمودي }
$$

بظهر مقطع هجران في شمال العراق الحد الفاصل بين تكوينين واسعي الانتنـار في العراق هما تكوين

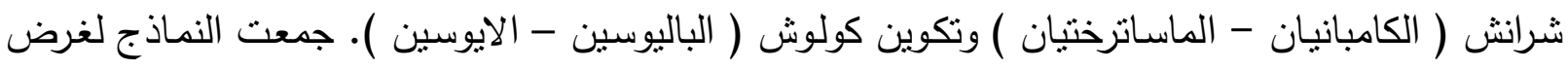

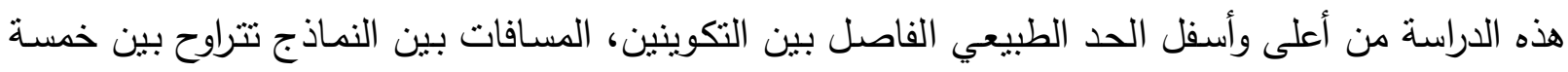

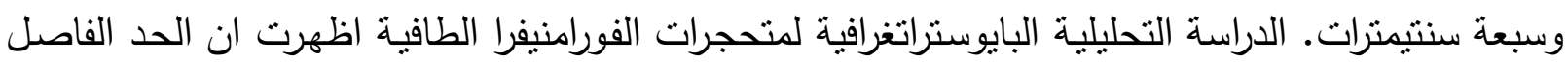

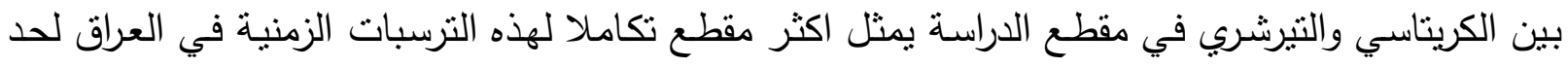

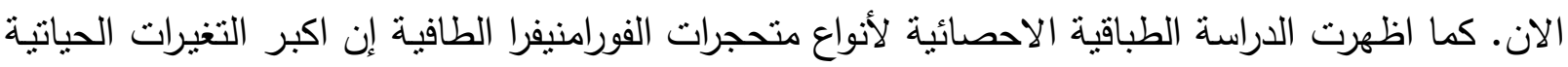

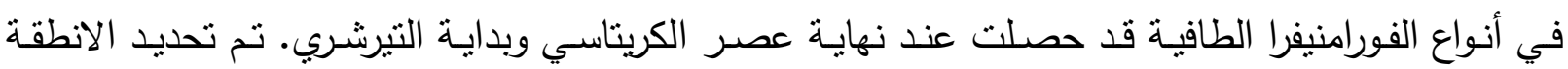
الحياتية التالية من خلال الدراسة الطباقية لنتحجرات الفورامنيفرا الطافية وهي لعصر الكريتاسي:

Gansserina gansseri Zone.

Abathomphalus mayaroensis Zone

Racemiguembelina fructicosa Subzone.

Pseudoguembelina hariaensis Subzone. 
High Resolution Biostratigraphy of the K/T boundary.

Pseudoguembelina palpebra Subzone.

$$
\text { أما الانطقة التي حددت للعصر التيرشري فهي: }
$$

Guembelitria cretacea Zone.

Parvularugoglobigerina eugubina Zone.

Parasubbotina pseudobulloides Zone and part of $t$.

Parasubbotina varianta Zone (Part).

وقد أثثتت الدراسة الحالية غياب النطاق Plummerita hantkeninoides ضمن تتابعات الكريتاسي

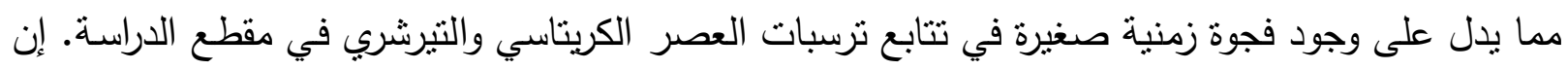

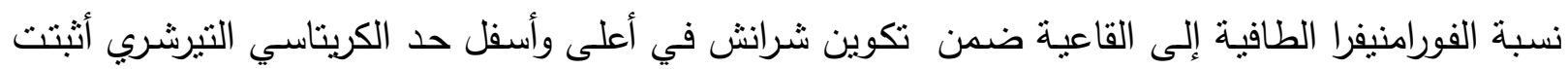

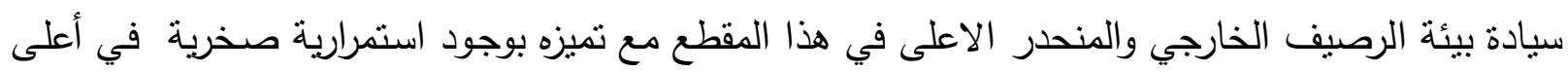

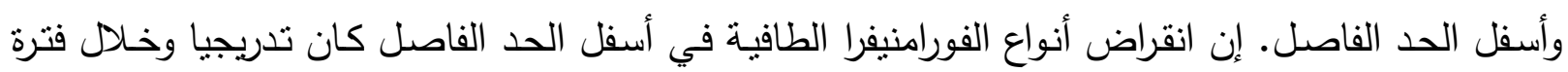

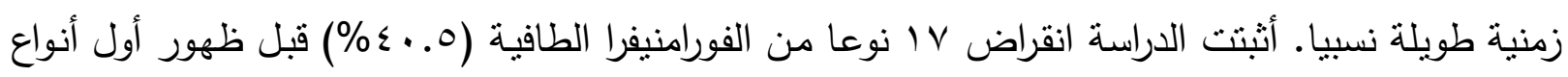

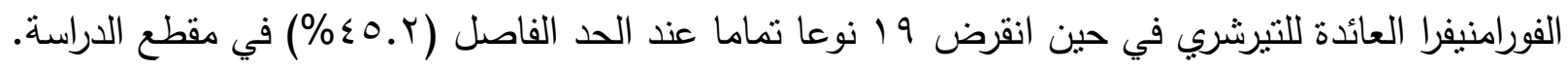

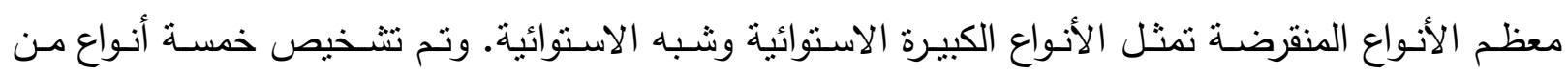

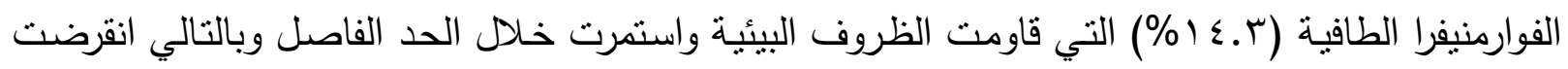

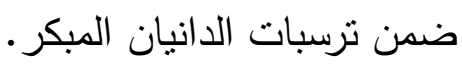
أثتتت الدراسة كذلك أن الدد الفاصل بين الكريناسي والتنيرشري يقع ضمن ترسبات المارل العائدة لتكوين شرانش، وليس عند الحد الفاصل بين تكوين شرانش وتكوين كولوش كما هو متعارف عليه في الادبيات

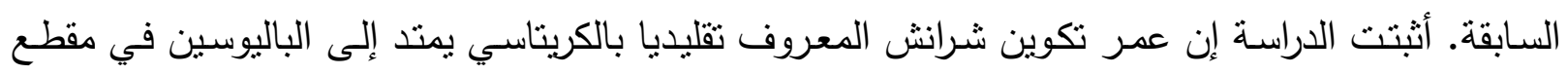

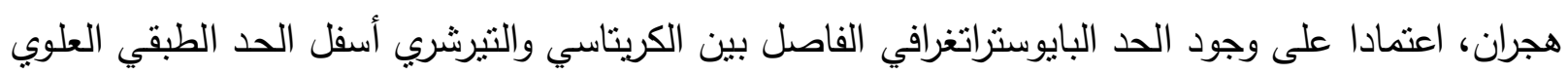
لتكوين شرانش بمسافة متر واحد.

\section{INTRODUCTION}

The Cretaceous / Tertiary boundary ( $\mathrm{K} / \mathrm{T}$ boundary) defines the end of the Mesozoic Era. The nature of the boundary event, and the related stratigraphic record and biotic changes (mode and rates of species extinction) have been subjected to intensive studies and much of debate and conflicting arguments for the last three decades according to different studies in different parts of the world. 
Several hypotheses have been proposed trying to explain the actual cause of the dramatic mass extinction at the end of the Cretaceous and its effect on the terrestrial and marine organisms. The most common causes that have been given to explain the catastrophic event are :

1- The intensive global sea level fluctuation as a result of climatic changes (Keller, 1988,1989 a and b, 1993, 1996 ; Schmitz et al. , 1992 ; Keller et al., 1993 ,1995, 1996, 2002; Pardo et al . 1996, 1999; Luciani, 1997,2002 ; Kaiho and Lamolda, 1999 ; Adatte et al. 2002; El -Sabbagh et al., 2004).

2- K-T boundary event was geologically instantaneous and catastrophic due to extraterrestrial cause of bolide (asteroid or cometary) impacts during the K/T boundary (Alvarez et al.1980, 1984; Smit and Hertogen, 1980; Smit,1990a, 1990b, 1999; Premoli Sliva and McNulty, 1984; Hildebrand and Boynton, 1990; Florentin et al., 1991; Smit et al, 1992 ; Liu and Olsson, 1992, 1994; Peryt et al., 1993, Coccioni and Galeotti, 1994, Molina et al, 1989, Arenillas et al., 2006).

3- Volcanisms and the effect of the main two gases ( $\mathrm{CO} 2$ and $\mathrm{SO} 2)$, which are released by basaltic eruption (Officer and Drake, 1985 ; McLean, 1985, 1991, 1994; Officer et al. 1987; Rampino and Stothers, 1988; Officer 1990; Glasby and Kunzendorf, 1996). These hypotheses generally share the likely effects of a drastic change that disrupting in the global ecosystem balance and caused a sharp increase of extinction rates in both continental and marine realms. A debate generated on the exact cause of the planktonic foraminifera mass extinction on the $\mathrm{K} / \mathrm{T}$ boundary, Keller, (1988, 1989a and b) argued that the extinction of the Cretaceous planktonic foraminiferal species was gradual and that some of them $(1 / 3$ of the species) survived and extended across the K/T boundary well into the Tertiary. Keller, (Op.Cit), Keller,(1993); Keller, et al., (1993, 1995, 1994, 2002); MacLeod and Keller (1996). Later, Pardo et al., $(1996 ; 1999)$ concluded that the tropical and subtropical foraminiferal taxa became extinct at or near the $\mathrm{K} / \mathrm{T}$ boundary whereas the cosmopolitan species tolerated the stress, survived and crossed the $\mathrm{K} / \mathrm{T}$ boundary into the base of the Danian in the low and middle latitudes. In the high latitudes however, the effect of the stress was less. According to Smit, (1980) all but one planktonic Cretaceous foraminiferal species suddenly became extinct exactly at the K/T boundary. He interpreted this dramatic faunal turnover as the result of a large bolide impact, this is also proven by (Smit and Hertogen, 1980; Premoli Sliva and McNulty, 1984; Smit, 1982, 1990a; Smit et al. 1992). He also mentioned that the only species that survived the $\mathrm{K} / \mathrm{T}$ boundary is the Guembelitria cretacea. 
In Tunisia the El Kef section was officially designated the $\mathrm{K} / \mathrm{T}$ boundary Global Stratotype Section and Point (GSSP) at the XXVIIIth International Geological Congress in Washington (1989) for being the most complete section with excellent preservation of microfossils, geochemical and mineralogical marker horizons. The exact boundary in this section is located at the base of the $50 \mathrm{~cm}$ of clay layer which defines the boundary worldwide. The stratotype provides ideal boundary transition with which other sections can be compared and correlated worldwide (Keller, 1993).

The K/T boundary sections in Iraq have been studied by different authors in different parts of Iraq. However, it has not yet been proven that there is a complete section in any part of Iraq comparing to the Global K/T boundary Stratotype Section and Point (GSSP) which contain a thin red clay layer and Iridium anomaly. The lithology and biostratigraphy of the upper Cretaceous and lower Tertiary formations in Iraq have been studied by different authors (Abawi, et al., 1982; Abdel-Kireem, 1983; Darmoian, 1975; Kassab, 1974; 1978; 1979; Mutawali, 1992, Al-Bazee, 2003). All of the previous studies proved that there was a period of nondeposition or erosion within the upper most Cretaceous and the Lower Tertiary within the $\mathrm{K} / \mathrm{T}$ boundary successions in Iraq.

\section{THE HIGRAN SECTION}

The studied Higran section is located on the southwestern limb of the Safine Anticline $1 \mathrm{Km}$ northeast of Higran village ( $36^{\circ} 25^{\prime} 15^{\prime \prime} \mathrm{N}, 44^{\circ} 15^{\prime} 55^{\prime \prime} \mathrm{E}$ ), in the Erbil Governorate of the Kurdistan Region in northern Iraq (Fig.1). The Cretaceous Shiranish Formation and the Tertiary Kolosh Formation are well exposed in the section. The thickness of the Shiranish Formation in the area is $150 \mathrm{~m}$ while the thickness of the Kolosh Formation is $450 \mathrm{~m}$. However, the thicknesses of these formations in Higran outcrop are almost 50 and 30 meters respectively. The Shiranish Formation is composed of gray to bluish hard, friable fine grained marl and marly limestone. In the field it looks like stratified marl with about $30 \mathrm{~cm}$ thick strata due to differential resistance to weathering between the marl and the marly limestone. The Tertiary Kolosh Formation comprises greenish shale with fine sandstones which contain various lithic fragments.

In the field, the $\mathrm{K} / \mathrm{T}$ boundary is very difficult to identify in the Higran section, there is no distinctive lithological break, clay layer, bioturbation, macrofossils, sedimentary structures, hard ground or erosional surface. 


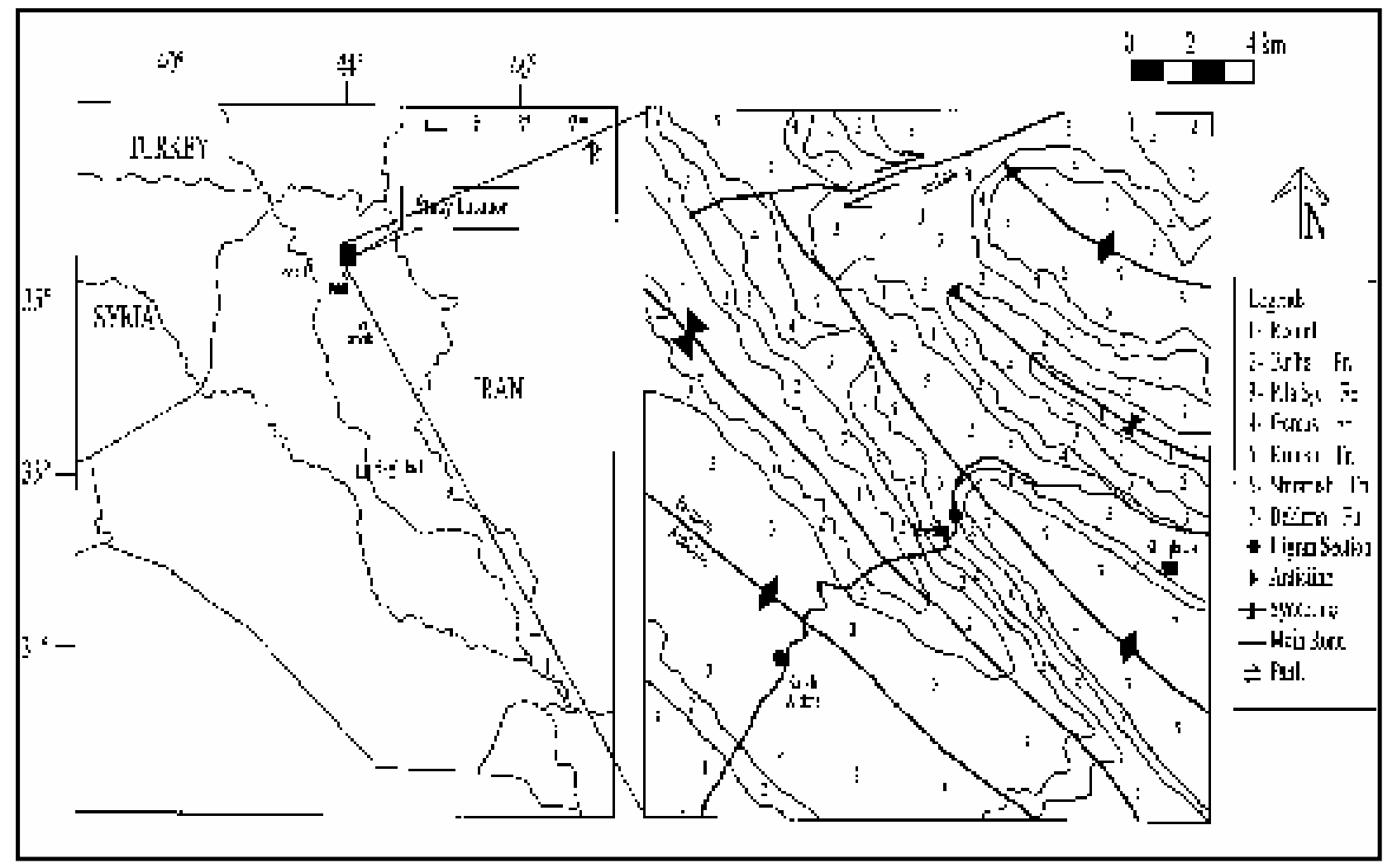

Fig. 1: Location map and geology of the study area.

\section{MATERIALS AND METHODS}

The section was trenched out to obtain fresh un-weathered samples from the top of the Shiranish Formation and the lower part of the overlying Kolosh Formation. Samples were collected at 20 to $30 \mathrm{~cm}$ interval across the critical K/T boundary. The foraminiferal analysis of these samples showed preliminarily the location of the $\mathrm{K} / \mathrm{T}$ boundary. A second visit to the section was made in order to collect more closely spaced samples. Thus another set of samples was collected at 5 to $7 \mathrm{~cm}$ interval well below and above the K/T boundary.

A total of 40 samples from above and below the $\mathrm{K} / \mathrm{T}$ boundary were analyzed in the course of this study. 
The collected samples were weighted and processed for foraminiferal analysis by standard micropaleontological techniques. The residues were split in three size fractions: $56-150 \mu \mathrm{m}, 150-250 \mu \mathrm{m}$, and $>250 \mu \mathrm{m}$. Planktonic foraminifera were examined from the three sieve-size fractions. Relative quantitative abundance percentage of the different species was made.

The classification of the Cretaceous genera and species followed the concept of Robaszyniski et al. (1984), Caron (1985), Huber et al., 2006, whereas the identification of the Paleocene species is based on Blow (1979), Toumarkine and Luterbacher (1985) and Olsson et al., (2000).

\section{BIOSTRATIGRAPHY OF THE HIGRAN SECTION}

The Higran section near the Shaqlawa Town is the most continuous Late Maastrichtian and Early Danian section recorded in Iraq up to date. The good preservation, highly diversified, rich foraminiferal number and the absence of evidence of reworking provided a good opportunity to test the extinction pattern of the Cretaceous foraminiferal species, the evolution of the Tertiary species and the biostratigraphic zonation for this section. The zonation of this section covers the span from the Late Maastrichtian (CF5) to Early Danian (Plc) foraminiferal zones (Fig. 2).The biostratigraphic zonation used in the Higran section is based on Li and Keller (1998) and Bergrren et al., (1995) for the Cretaceous and Tertiary respectively. This zonation is correlated with other works in different parts of the world. Age and Zonal correlations were also made with the Cretaceous / Tertiary boundary stereotype of the Tunisia El Kef section as made by Li and Keller (1998) and Li et al., (1999) and the same boundary in Dakhla Formation in Egypt (Fig.3). The biozonation for the Maastrichtian and Danian datum events and biozones in Dakhla Formation in Egypt are broadly valid for the eastern Tethys region Tantawy et al., (2001).

In this study the first and last appearances of the foraminiferal species are used to obtain the biostratigraphic zones. The stratigraphic range of the species is shown in the range chart of the species (Fig. 2). The quantitative presence of the species is shown in Figs. $(4,5,6,7)$. 
Rund A. Hammoudi

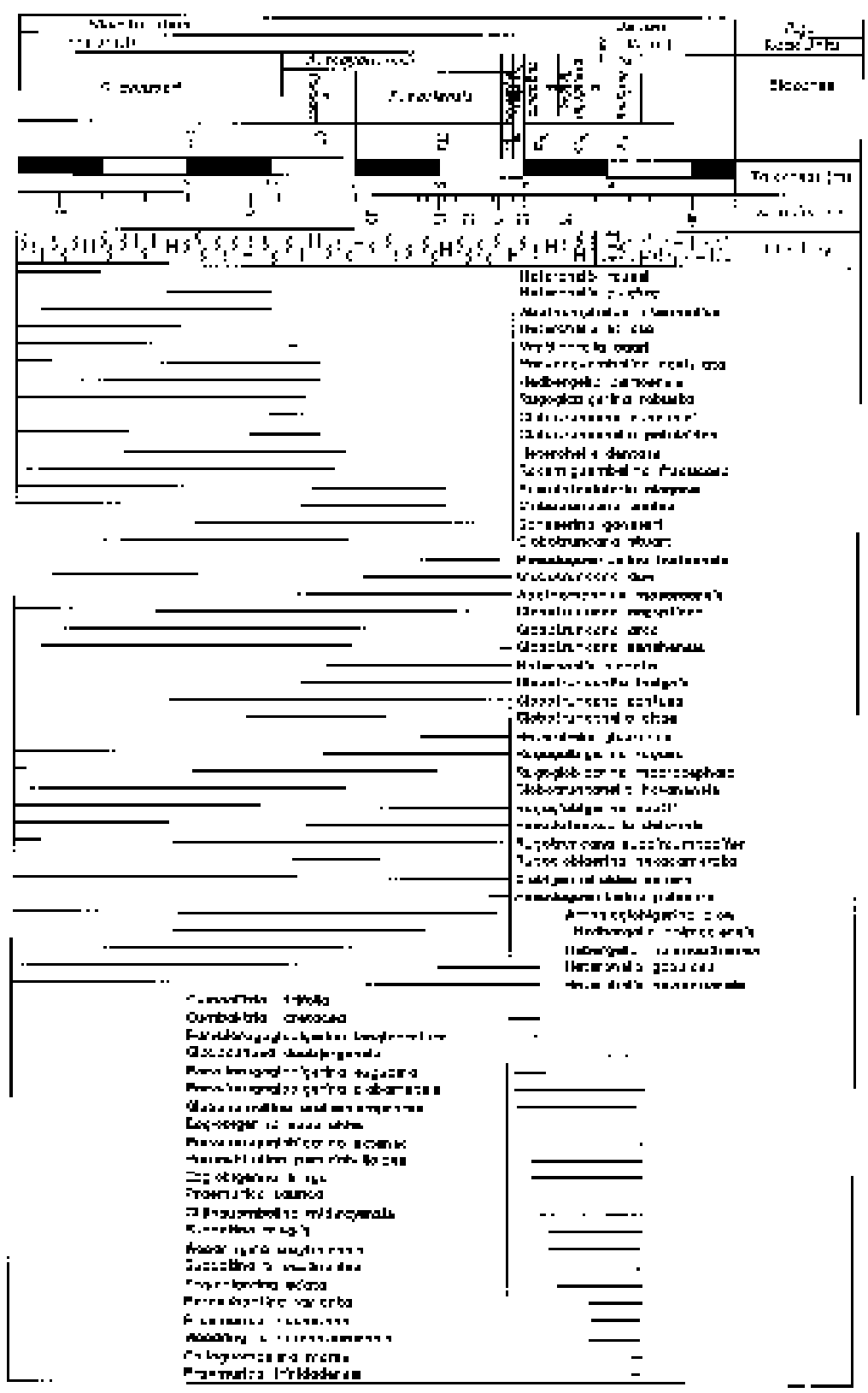

Fig. 2: Biostratigraphic Range Chart of the Planktonic Foraminifera in Higran Section N. Iraq. 
High Resolution Biostratigraphy of the K/T boundary

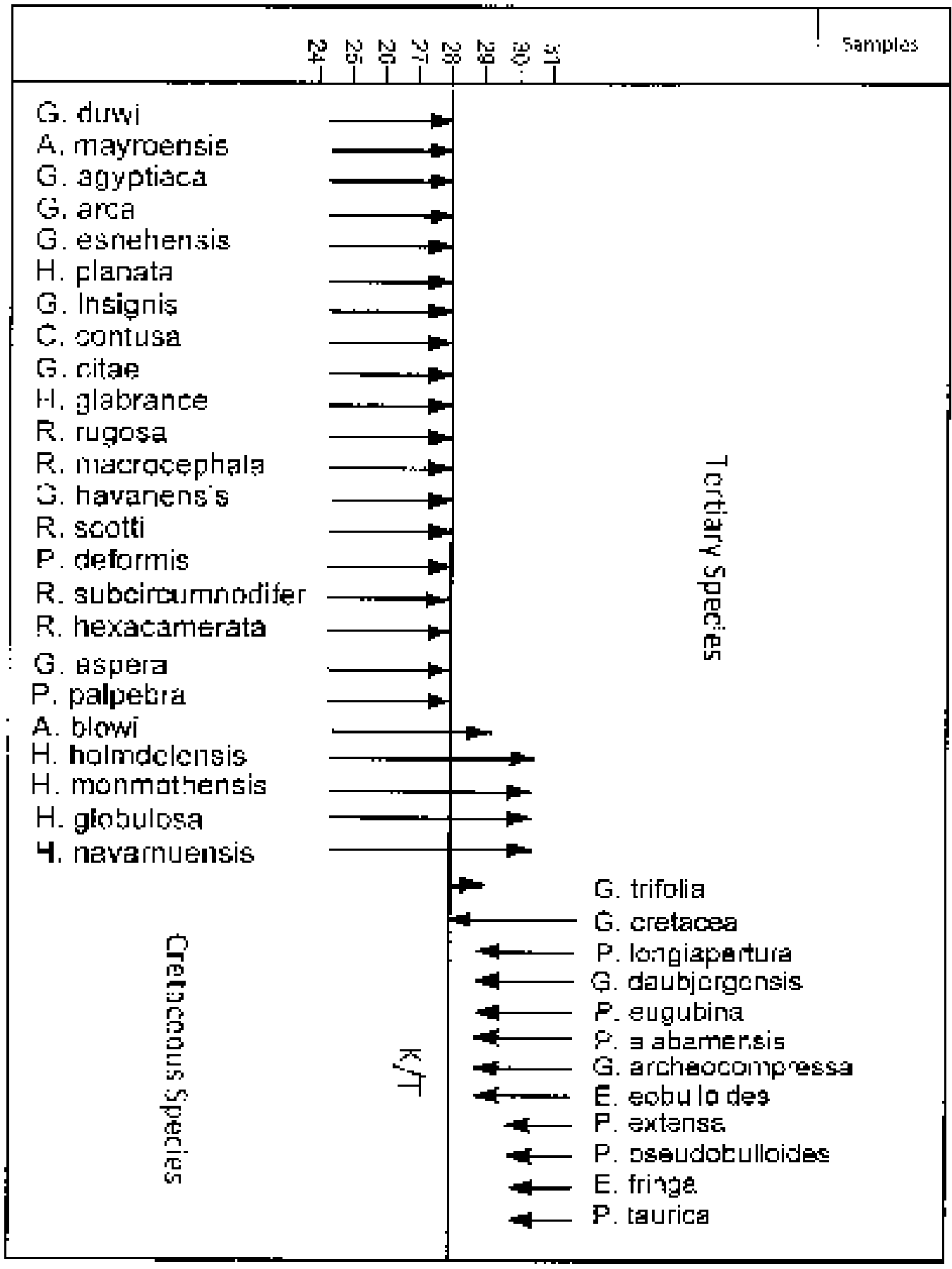

Fig. 3: Schematic Diagram of the Foraminiferal Bioevents at the K/T Boundary in Higran Section N. Iraq. 

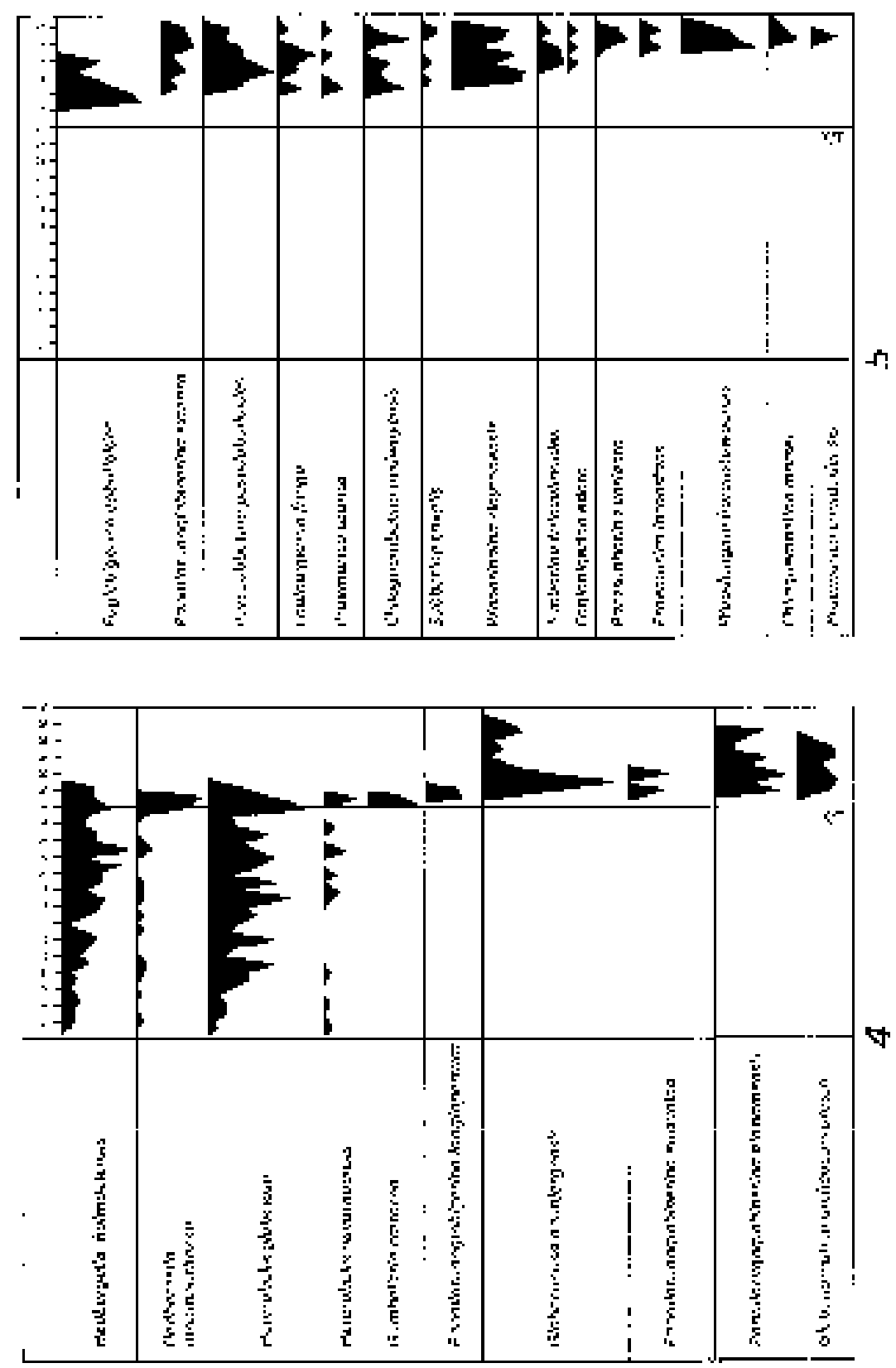

Fig. 4,5: Relative Species Abundance of Planktonic Foraminifera Across the K/T Bounday in Higran Section Shaqlawa Area N. Iraq. 


\section{LATE MAASTRICHTIAN ZONES}

The Late Maastrichtian Zones include the interval from the Gansserina gansseri zone to the P.pelpera subzone in the studied section.

\section{Gansserina gansseri Zone (Part)}

Interval Zone of the nominate taxon Gansserina gansseri (Bolli) between its first appearance and the first appearance of the Abathomphalus mayaroensis (Bolli). This zone is comparable with the Pseudotextularia intermedia Zone (CF5) of Li and Keller (1998). The lower boundary is not covered by this section and the upper boundary is defined by the first appearance of the Abathomphalus mayaroensis (Bolli ).This zone is conformably overlain by the Abathomphalus mayaroensis Zone.

\section{Abathomphalus mayaroensis Zone}

Total Range Zone of the nominate taxon (Abathomphalus mayaroensis (Bolli). The upper and lower boundaries were drawn with the first and last occurrences of the nominate taxon.

This zone is coeval with the standard zonation of Caron, 1985 and Berregren et al., 1995, it also coincide with the zones CF4, CF3, CF2, of Li and Keller 1998. Thus, the Abathomphalus mayaroensis Zone is subdivided into three subzones in the studied section according to the planktonic foraminiferal bioevents. These are:

\section{Racemiguembelina fructicosa Subzone}

Partial Range Subzone of the nominate taxon Racemiguembelina fructicosa (Egger). The lower boundary was drawn with the first appearance of the Abathomphalus mayaroensis. The first occurrence of the Pseudogumbelina hariaensis( Nederbragt) defines the upper boundary of this subzone.

The Racemiguembelina fructicosa subzone CF4, was defined by Li and Keller (1998) as a partial range of the nominate taxon between the first appearance of the Racemiguembelina fructicosa (Egger) and the first appearance of the Pseudoguembelina hariaensis (Nederbragt). In this study the first appearance of the Racemiguembelina fructicosa is below the first occurrence of the Abathomphalus mayaroensis. Thus the first appearance of the datum taxa A. mayaroensis is taken here to define the lower boundary of this subzone.

\section{Pseudoguembelina hariaensis Subzone}

Interval subzone of the nominate taxon Pseudoguembelina hariaensis (Nederbragt). The lower boundary of this zone was defined by the first occurrence of the Pseudoguemblina hariaensis and the upper boundary was defined by the first 
occurrence of Pseudoguembelina palpebra. This subzone is comparable with the Zone CF3 of Li and Keller (1998).

\section{Pseudoguembelina palpebra Subzone (Part)}

Interval subzone of the nominate taxon Pseudoguembelina palpebra (Brönnimann). The lower boundary is defined with the first occurrence of the Pseudoguembelina palpebra and the upper boundary is located with the first appearance of the Paleocene taxa. This subzone is comparable with the lower part of the CF2 zone of Li and Keller (1998).

The upper boundary of this subzone shows the turnover of the Cretaceous in this section, with the absence of the most important Late Maastrichtian biomarker Plummerita hantkeninoides for the $\mathrm{K} / \mathrm{T}$ boundary.
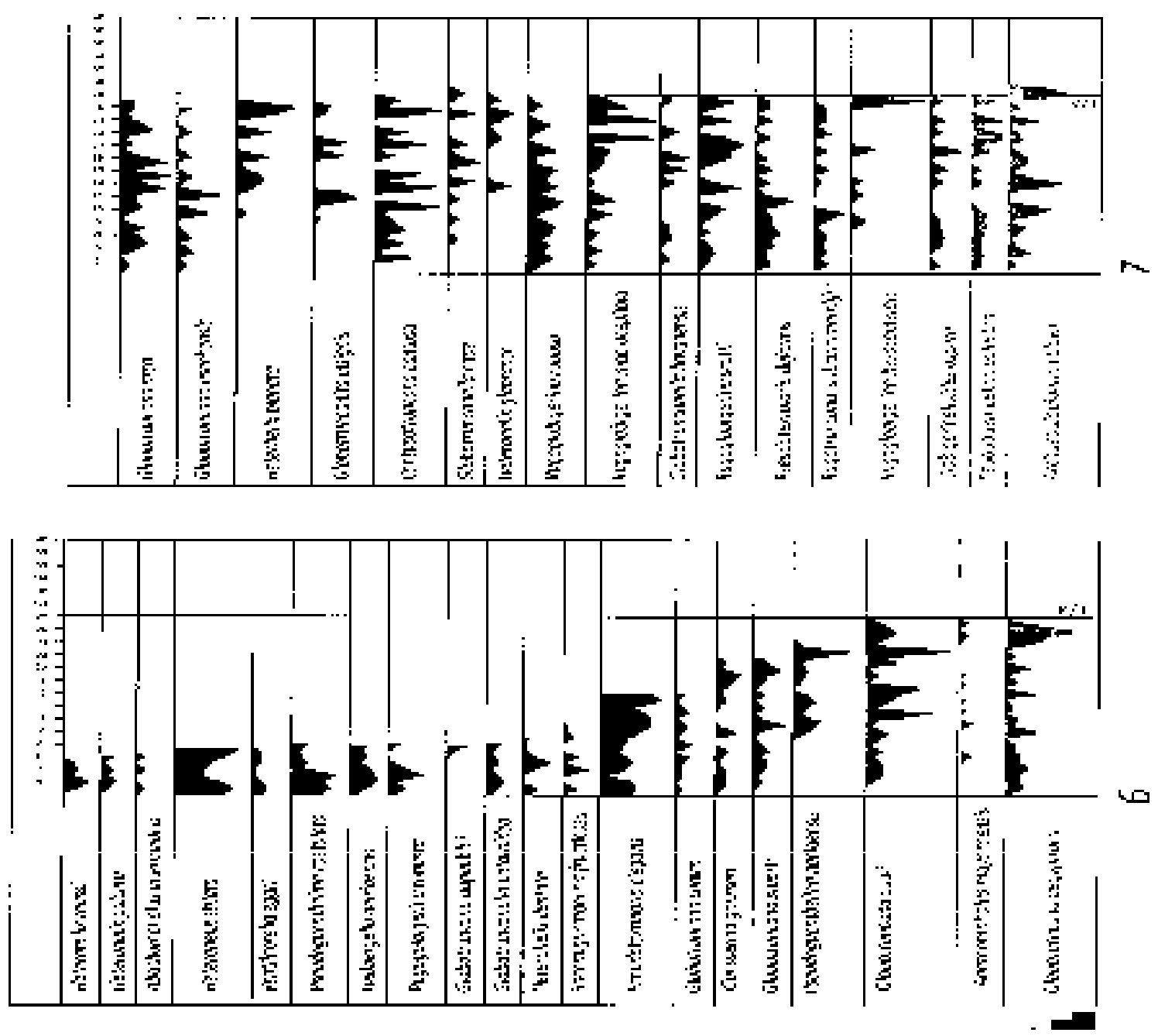

Fig. 6,7: Relative Species Abundance of Planktonic Foraminifera Across the K/T Boundary in Higran Section Shqlawa Area, N. Iraq. 
High Resolution Biostratigraphy of the $\mathrm{K} / \mathrm{T}$ boundary

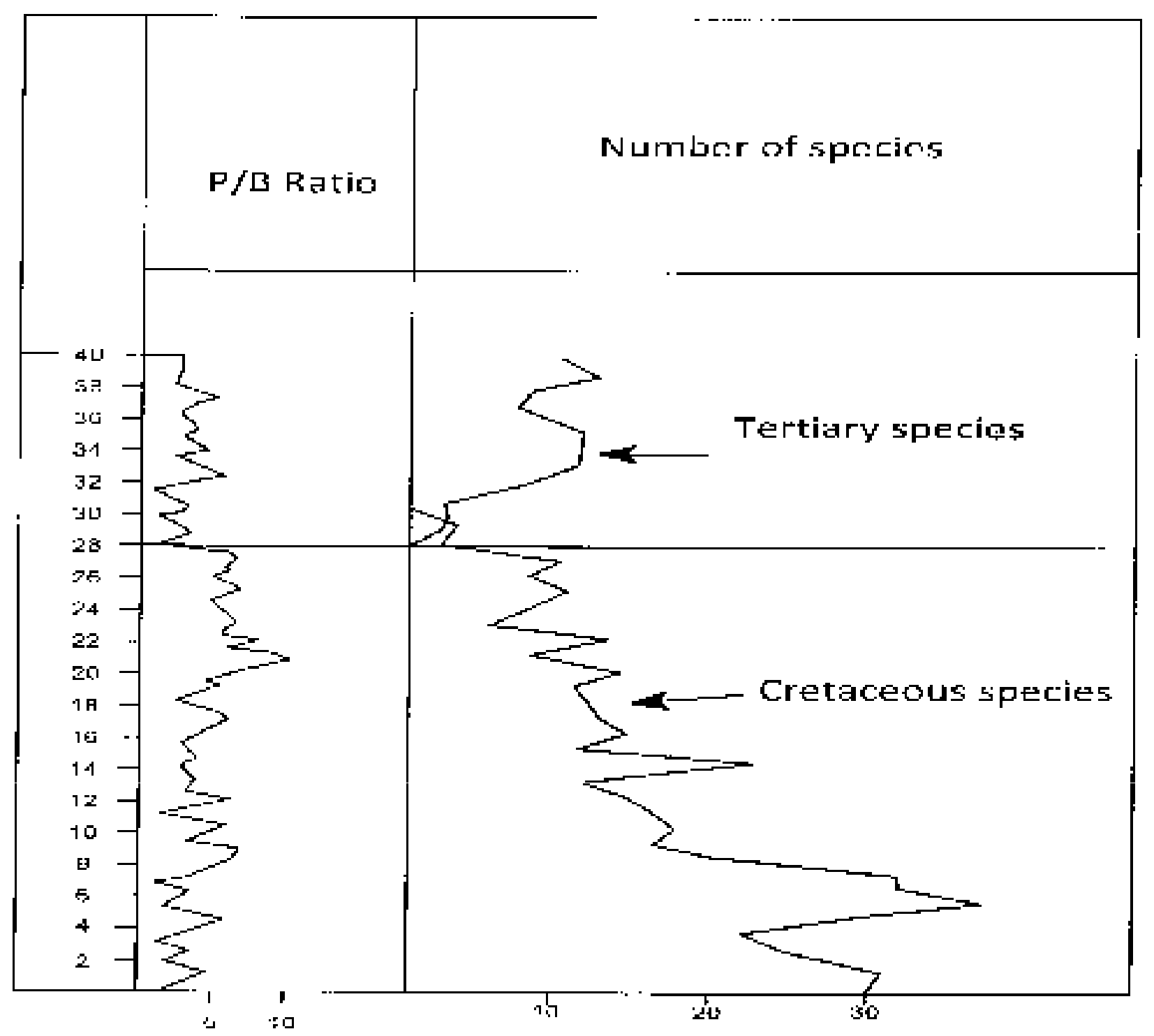

Fig. 8: Schematic Diagram of Planktonic (P) to Benthonic (B) Ratio and Number of Foraminiferal Blanktonic Species Across the K/T Boundary in Higran Section N. Iraq.

\section{THE EARLY TERTIARY ZONES}

The Early Tertiary Zones in this section started from the Guembelitria cretacea Zone to the lower part of Parasubbotina varianta Zone, it represents the presence of the Danian succession in the studied section, these zones are : 


\section{Guembelria uemblitria Cretacea Zone}

Interval Zone of the nominate taxon Guembelitria cretacea Cushman between the first occurrence of the Guembelitria cretacea and the turnover of most of the Cretaceous species to the first occurrence of the Parvularugoglubigerina eugubina (Luterbacher and Premoli Silva). This zone is comparable with the zone P0 of the standard zonation of Berggren et al., (1995), and the zone P0 of Keller, (1988); Keller et al., (1995); Li and Keller, (1998). This zone is defined as the interval between the extinction of Cretaceous tropical planktonic foraminifera and the first appearance of Parvularuguglobigerina eugubina and / or P. longiapertura Keller et al., (1995). Generally Zone P0 is marked by a dark clay layer with thin red clay at the K/T boundary, In the present study, careful examination of the base of this zone which mark the K/T boundary shows no lithological break and no discernable clay layer on the mega scale. This zone is very limited in thickness $(10 \mathrm{~cm}$.) which defined according to the presence of the Guembelitria cretacea in two of the samples

(samples no 28 and 29). The abesnece of the species Plummerita hantkenoides and Kassabina falsocalcarta in these two samples and the absence of A. mayaroensis and P. palpebra marked this interval to be the G. cretacea zone (P0) rather than being part of Abathomphalus mayaroaensis Zone. Most of the Cretaceous foraminifera disappear at the lower boundary of this zone, Rare occurrences of Hedbergella monmouthensis, H. holmdelensis, Heterohelix globulosa and H.navaroensis, Archaeoglobigerina blowi, Guembelitria trifolia is recorded within this zone. These Cretaceous species were extended from the Cretaceous through the $\mathrm{K} / \mathrm{T}$ and disappear within this zone. Generally the planktonic foraminifera are rare within this zone.

\section{Parvularugo globigerina eugubina Zone}

Total Range Zone of the nominate taxon Parvularugoglobigerina eugubina (Luterbacher and Premoli Silva). This zone is comparable with the zone P. eugubina of the standard zonation of Berggren et al., (1995), and the zone P1a( 1,2 ) of Keller et al., (1995); Li and Keller, (1998) .

\section{Parasubotine pseudobull Oides Zone}

This is the Partial Range Zone of the nominate taxon P.pseudobulloides (Plummer), marked from the last appearance of Parvularugoglobigerina eugubina (Luterbacher and Premoli Silva) to the first occurrence of the S. triloculinoides. This (1995) and the zone P1b of; Li and Keller, (1998).

\section{Parasubotine varianta Zone(Part)}

This Interval zone is defined from the first appearance of the nominate species Parasubbotina varianta (Subbotina) to the first appearance of Praemurica trinidadensis, Keller , (1988); Keller et al., (1995). This zone is comparable with 
the lower part of the zone P1b of standard zonation of Berggren et al., (1995) and the zone P1c of Keller, (1988); Keller et al., (1995) and Li and Keller, (1998) .

\section{K/T Bound Bioevents}

The time that is represented by the Cretaceous/Tertiary boundary was characterized by mass extinction of tropical and subtropical planktonic foraminiferal species (Olsson, 1997; Keller, 2001). The mass disappearance of the species constitutes the largest and most sudden extinction event in the history of planktonic foraminifera, (Molina et al., 1998). In the Higran section, the Cretaceous planktonic foraminiferal turnover occurred gradually and during relatively long period, (Fig. 9). Foraminiferal study shows that $40.5 \%$ of the species disappeared before the end of Maastrichtian (within G. gansseri Zone, R. fructicosa subzone, P. harianesis Subzone and P. palperbra Subzone). The Late Maastrichtian species that became extinct exactly at the K/T boundary ( $45.2 \%$ of the total number of species) were large, complex tropical and subtropical forms that dwelled in deep and intermediate water depths such as (Globotruncana duwi, G. aegyptiaca, G. arca, G. esnehensis, Globotruncanella citae, Contusotruncana contusa, Rugoglobigerina rugosa). Nevertheless, the small cosmopolitan generalists surface dwellers with simple morphologies (14.3\% of the species) appear to have survived the $\mathrm{K} / \mathrm{T}$ boundary and the drastic change in the ecosystem and gradually became extinct in the Early Danian.These are the G. cretacea, H. holmdelensis, H. monmouthensis, H. globulosa, H. navaroensis, and A. blowi. The author classified the tropical subtropical and cosmopolitan species in this work depending upon the classification by Keller et al.,(1995).

The evidences in favor of an uppermost Maastrichtian hiatus in the Higran section are:

1- The extinction of Cretaceous zonal marker planktic foraminiferal species (Fig.9).

2- The absence of the P.hantkinoides in the (CF1 Zone) in the Higran section below the first appearance of the Tertiary species.

3- Kassabina falsocalcarta is not recognized in the section which also gives strong indication of the missing of the upper most part of Maastrichtian.

4- The last occurrence of the Gansserina gansseri is observed well below the first occurrence of Danian species, this indicates of the uppermost Maastrichtian hiatus with the missing of the upper part of the zone CF2 and total missing of the zone CF1.

5- This hiatus is also suggested by the relatively short range of P. hariaensis.

It is quite common to have a hiatus at the $\mathrm{K} / \mathrm{T}$ boundary because of the sea level low stand in the latest Maastrichtian CF1 zone (Adatte et al., 2002). In the Tertiary, the Cretaceous species that survived the K/T boundary in the P0 zone are the generalist small heterohelicides and hedbergellids .They were identified in small 
size and low abundance. The opportunistic species Guembelitria cretacesa has a distinctive appearance within the P0 Zone, while Guembelitria trifolia appears within the $\mathrm{P} 0$ zone and is distinctively present within the $\mathrm{P} 1 \mathrm{a}$ subzone. These fauna are also recognized by Keller et al., (2001) in zone P0 of the El Kef section in Tunisia and in Dakhla section in Egypt (Tantawi et al., 2001); and by Obaidalla, (2005) in Wadi Nukhul section in southwestern Sinai, Egypt .

The Planktonic to Benthonic ratios across the $\mathrm{K} / \mathrm{T}$ boundary in Higran section are indicates the prevalence of the outer shelf to upper slope environments well above and below the K/T boundary in the section (Fig. 8). The succession above and below the boundary is characterized by lithologic continuity and a short missing interval.

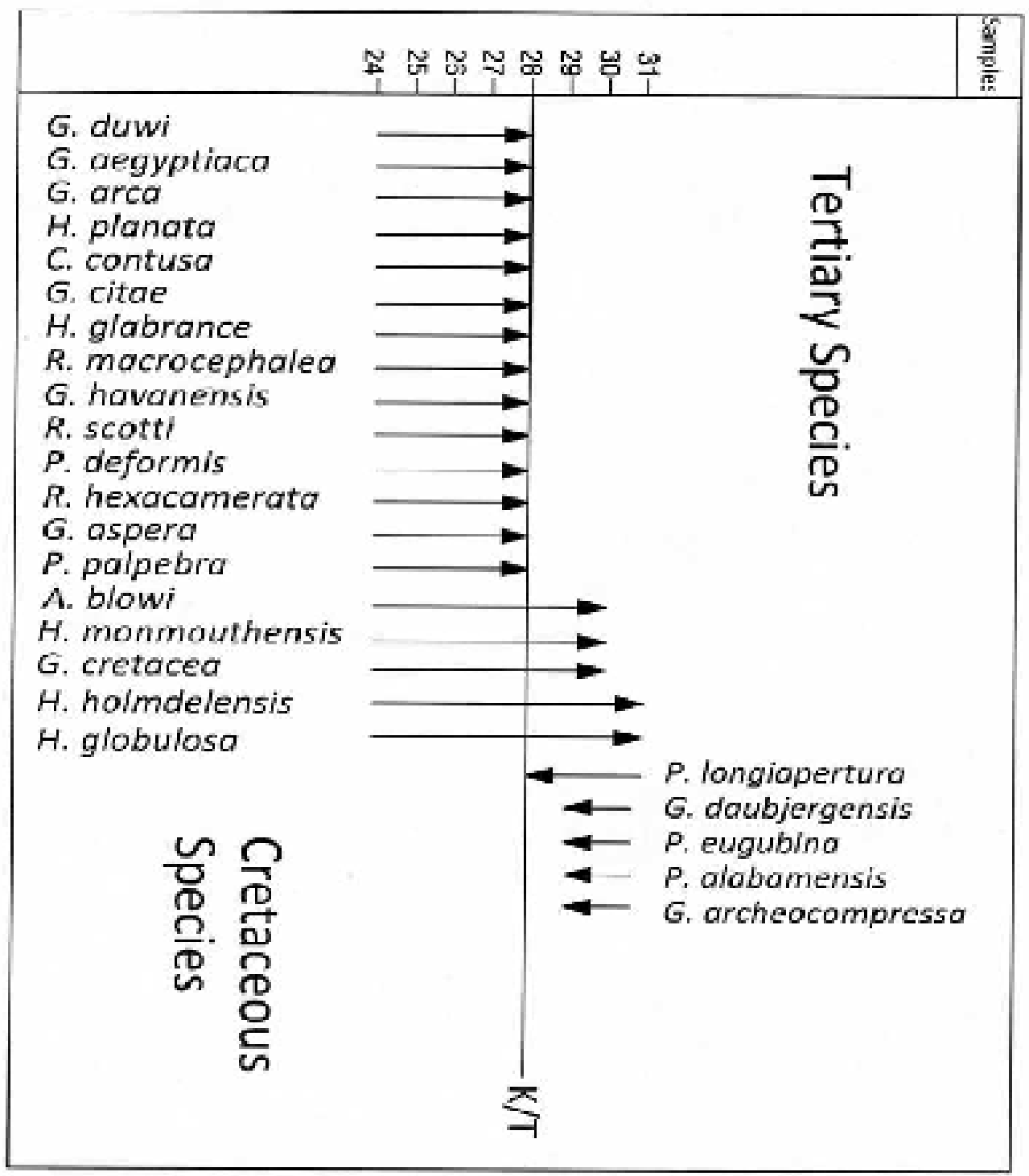

Fig. 9: Foraminferal Bioevents at the K/T Boundary in Higran Section N. Iraq. 
High Resolution Biostratigraphy of the K/T boundary.

Table 1: Comparison of the Uppermost Maastrichtian and the Lowermost Danian Plantonic Forminiferal Biozonation with the Biozonation of this Paper

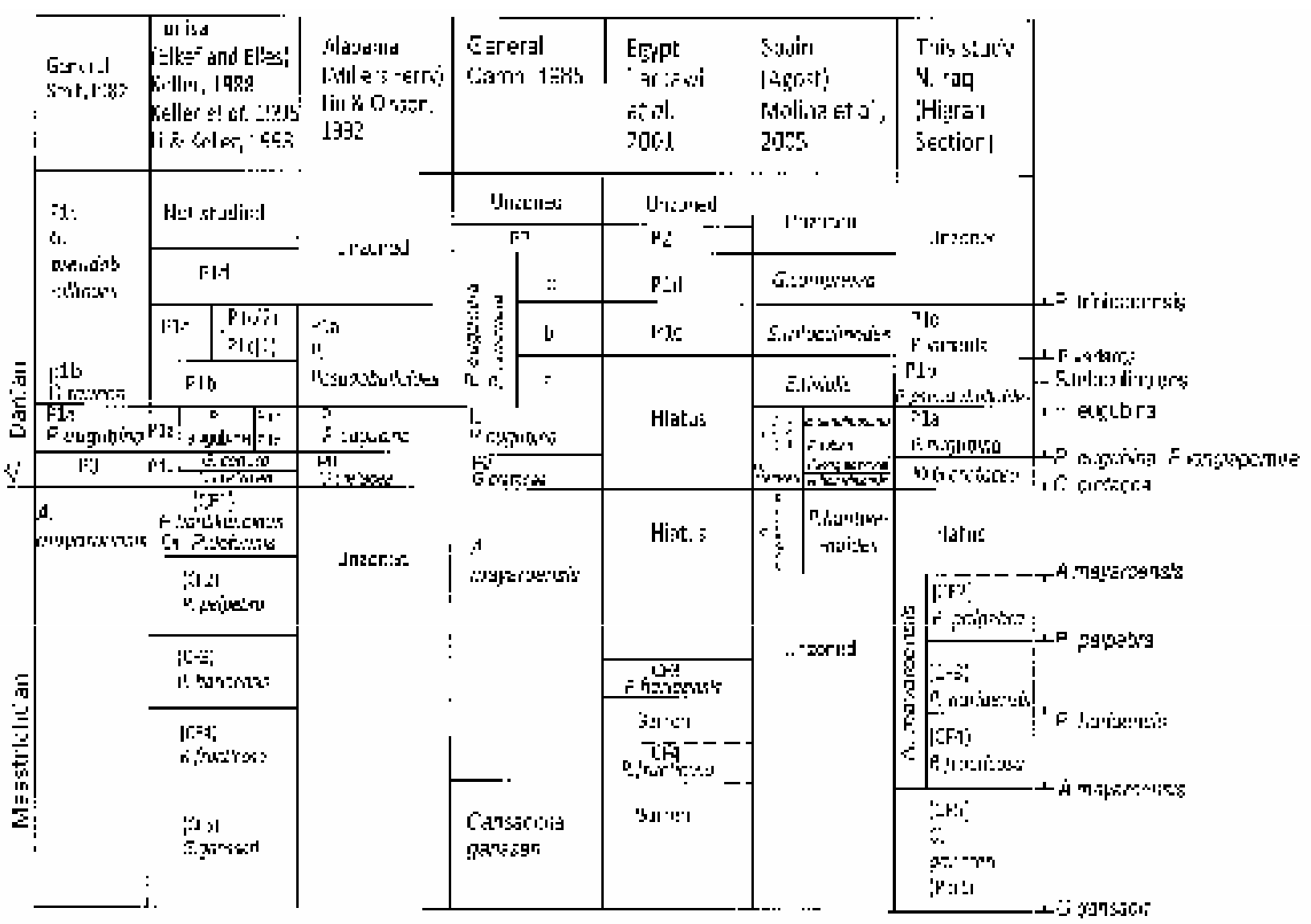

\section{DICHRONUSITY OF THE SHIRANISH FORMATION}

Shiranish Formation is the most extensive Upper Cretaceous formation in north and middle parts of Iraq. The formation was first described by Henson 1940 in unpublished report. Then Bellen et al., (1959) gave the age Upper Cretaceous; Maastrichtian for the top of the formation, and Maastrichtian or Late Upper Campanian for its base. This recognition of the age was followed by very many foraminiferal biostratigrphic studies which also assigned the age of Maastrichtian or Campanian to Maastrichtian to the Shiranish Formation in Iraq. This study however, has shown that the age of the Shiranish Formation extends to the Paleocene in the Higran section. The turnover of the Cretaceous foraminifera which defines the end of the Cretaceous is in reality located one meter below the physical contact between the Shiranish and the Kolosh formations. Lithologically, the K/T boundary is proven to be located within the blue marl of the Shiranish Formation. 
This study also shows the presence of a short hiatus in the upper part of the formation by the absence of the upper part of the zone CF2 and the zone CF1.

\section{DISCUSSION}

The (GSSP) defines the geochronologic boundary as a point in the rocks, which represents some event in the earth's history that can be recognized outside the type section (Remane, 2003). For the K/T boundary this point is the lithological change between the Cretaceous and the Tertiary and usually consists of a dark clay layer with a thin red layer at the base, which may or may not contain anomalous concentrations of Iridium. The defining criteria or the primary markers of the geochronologic boundary include first and foremost, fossils or unique geochemical signal and magnetic reversal (Keller et al., 2004). In the Higran section the lithotypes below and above the K/T boundary are the same which is marl and marly limestone of the Shiranish Formation. Careful examination of the boundary shows no evidence of dark clay thin layer, boring or borrowing or hard ground, so there is no sharp lithological break. In general, the continuity of the stratigraphic record is variable and depends on the paleoenvironment and depth of sediment deposition. In shallow water sequences sedimentation is often interrupted by erosion or nondeposition due to global cooling, intensified current activity and sea level changes or tectonic activity. The most complete sequences with the highest rates of sedimentation occur in continental margin settings spanning outer shelf to upper slope environments. (Keller et al., 2002b). However in the Higran section the contact is marked by missing interval within lithological continuity.

In this study the foraminifera is studied as the only proxy to locate the exact position of the $\mathrm{K} / \mathrm{T}$ boundary with the use of the mass extinction of the Cretaceous foraminifera and the evolution of the Tertiary foraminifera as the primary $\mathrm{K} / \mathrm{T}$ marker. The High resolution study of the Higran section in Northern Iraq shows extremely rich planktonic foraminifera. The biostratigrphic analysis of these planktonic foraminifera gave the indication of the presence of a hiatus. Nevertheless, the studied section can still be regarded as the most complete Cretaceous/Tertiary section up to date in Iraq. The hiatus is in the uppermost Maastrichtian, it covers the upper part of CF2 and CF1.

Following (Murray, 1976) ranking, the planktonic to benthonic ratio obtained in this study for the Shiranish Formation across the K/T boundary shows the presence of the outer shelf to upper slope environment (Fig. 9). Thus for the Higran section, the $\mathrm{K} / \mathrm{T}$ boundary is marked more by lithological continuity rather than missing interval.

The Pattern of extinction of the Late Maastrichtian fauna has been a matter of debate. Smit (1977, 1990a) believed that the bolide impact event caused the extinction of all Cretaceous fauna except for one species (G.cretacea) and he 
considered the presence of the Cretaceous fauna within the Tertiary sediments as due to reworking, while Keller, (1988) figured out that the Cretaceous extinction pattern of the foraminifera are gradual and that ten foraminiferal species survived the K/T catastrophe into the Danian sediments at the El Kef (GSSP) in Tunisia. Keller (op.cit) contends that the extinction was due to drastic change in the ecosystem and unrelated to an impact event. The study of the pattern of extinction in the Higran section shows that the turnover of the Cretaceous fauna is gradual and ranging from the subzone P.hariensis to the zone P1a in the Tertiary (Fig. 9). It is therefore concluded that there is no evidence of a bolide impact in the Higran section. Gradual models of extinction have also been recorded from low latitude continuous sections in different parts of the world such as Agost and Caravaca, Spain (Canudo et al., 1991; Pardo et al., 1996).

\section{CONCLUSIONS}

The Cretaceous Shiranish Formation and the Tertiary Kolosh Formation are well exposed in the Higran section in northern Iraq with a biostratigraphically well defined $\mathrm{K} / \mathrm{T}$ boundary.

The fine biostratigraphic analysis carried out in this study has revealed that the K/T boundary is located in the same lithology of blue marls within the Shiranish Formation, rather than at the contact between the Shiranish and Kolosh formations. It has thus been shown that the well-known Shiranish Formation conventionally taken to be of Cretaceous age actually extends into the Paleocene in the Higran section. In essence the turnover of the Cretaceous foraminifera is located one meter below the physical contact between the Shiranish and Kolosh formations.

The Maastrichtian Gansserina gansseri and the Abathomphalus mayaroensis Zones were recognized. The Abathomphalus mayaroensis Zone was subdivided into three subzones they are: Racemiguembelina fructicosa Subzone, Pseudoguembelina hariaensis Subzone and part of Pseudoguembelina palpebra Subzone. The defined Tertiary zones are: Guembelitria cretacea Zone, Parvularugoglobigerina eugubina Zone, Parasubbotina pseudobulloides Zone and part of the Parasubbotina varianta Zone.

The planktonic to benthonic ratios of the Shiranish Formation across the K/T boundary indicates the role of the outer shelf to slope environments well above and below the K/T boundary in the studied section; hence it is characterized by lithological continuity and relatively short missing interval.

Evidence suggests that this section can be regarded as hitherto the most complete $\mathrm{K} / \mathrm{T}$ boundary section in Iraq. However, this study has established the absence of the Plummerita hantkeninoides Zone within the Cretaceous succession 
indicating a short hiatus (Diastem) between the Cretaceous and Tertiary successions in the Higran section.

Quantitative high resolution foraminiferal biostratigraphic analysis has shown that a major foraminiferal turnover of the planktonic foraminifera occurred during the end of the Cretaceous to the beginning of the Tertiary. It has also been shown that the turnover was gradual ranging from the subzone $\mathrm{P}$. hariensis in the Cretaceous to the zone P1a in the Tertiary and that the extinction was due to drastic change in the ecosystem and unrelated to a bolide impact event.

The quantitative analysis for the Higran section has shown that Seventeen species ( $40.5 \%$ of the Cretaceous species) became extinct in the Late Maastrichtian before the first appearance of the Tertiary species, whereas nineteen species (45.2\%) disappeared exactly with the hiatus that defines the $\mathrm{K} / \mathrm{T}$ boundary in the studied section. Most of the extinct forms are large, complex, tropical and subtropical. It is also significant that $(14.3 \%)$ of the Cretaceous foraminiferal species in the Higran section (in particular the small cosmopolitan generalists with simple morphologies) survived the K/T boundary and the drastic change in the ecosystem. They did however become extinct in the Early Danian.

\section{ACKNOWLEDGMENT}

The author would like to express her thanks and gratitude to Prof. Dr. Tarik S. Abawi from the Dept. of Geology at Mosul University for reviewing the manuscript of this paper and for the continuous discussion during the production of this work.

\section{REFERENCES}

Abawi, T. S., M. R. Abdel Kireem, J. M. Yousif, 1982. Planktonic Foraminifera Stratigraphy of Shiranish Formation, Sulaimaniah / Dokan Region NE Iraq, Revista Espanola De Micropaleontologia, V. XIV, pp. 153 - 164.

Abdel-Kireem, M. R., 1983. A Study of the Paleoecology and Bathymetry of the Foraminifera Assemblages of the Shiranish Formation (Upper Cretaceous) NE Iraq, Paleog. Paleoc., Vol. 43, pp. 169 - 180.

Adatte, T., G., G. Keller and W. Stinnesbeck, 2002. Late Cretaceous to Early Paleocene Climate and Sea-Level Fluctuations: Palaeoclimatology, Palaeoecology, Palaeogeography, Vol.. 178, pp. 165 - 196.

Al-Bazee, N. T., 2003. Foraminiferal and Ostracoda of Upper Cretaceous-Lower

Tertiary Contact from Selected Sections N.Iraq, Unpublished MSc thesis, Baghdad University, 107p.

Alvarez, L. W., W. Alvarez, F. Asaro and H. V. Michel, 1980. Extraterrestrial Cause for the Cretaceous-Tertiary Extinction. Science,Vol. 208, pp.1095-1108. 
Alvarez, W., L. W. Alvarez, F. Asaro and H. Michel, 1984. The end of the Cretaceous : Sharp Boundary or Gradual Transition ?. Science, Vol. 233, pp. $1183-1186$.

Bellen, R. C. Van, V. H. Dunnington, R. Wetzal and D. Morton, 1959. Lexique Stratigraphique International, Asie Fascicule, 10a -Iraq, Paris, 333p.

Arenillas, I, J. Arz a, J. Grajales-Nishimura, G. Murillo-Muñetón, W. Alvarez, A. Camargo-Zanoguera, E. Molina, C. Rosales-Domínguez, 2006. Chicxulub Impact Event is Cretaceous/Paleogene Boundary in Ege: New Micropaleontological Evidence, Earth and Planetary Science Letters, Vol. 249, pp. 241 - 257.

Berggren, W. A., D. V. Kent, C. C. Swisher, and M. P. Aubry, 1995. A Revised Cenozoic Geochronology and Chronostratigraphy. In Berggren, W. A., Kent, D.V., Aubry, M. P. and Hardenbol, J. (Eds.), Geochronology, Time Scales and Global Stratigraphic Correlation. Spec. Publ. Soc. Econ. Paleontol. Mineral., Vol. 54, pp. 129 - 212 Tulsa, Oklahoma.

Blow, W. H., 1979. The Cainozoic Globigerinida, 3 Vols., Brill, Leiden. 1413 p. Canudo, J. I., G. Keller, Molina, E., 1991. Cretaceous/Tertiary Boundary Extinction Pattern and Faunal Turnover at Agost and Caravaca, S. E. Spain. Marine Micropaleontology, Vol. 17, pp. 319 - 341.

Caron, M., 1985. Cretaceous Planktic Foraminifera, In Bolli, H. M., J. B. Saunders, and K. Perch-Nielsen, (Eds.), Plankton Stratigraphy: Cambridge (Cambridge Univ. Press), pp. 17 - 86.

Coccioni, R. and S. Galeotti, 1994. K-T Boundary Extinction; Geologically Instantaneous or Gradual Event? Evidence from Deep-Sea Benthic Foraminifera, Geology, Vol. 22, No. 9, pp. 779 - 782.

Darmoian, S., 1975. Stratigraphy and Micropaleontology of the Upper Cretaceous Aruma Suppergroup SE Iraq, Jour. Geol. Soc. Iraq, Spec. Iss. Pub. pp. $151-209$.

El-Sabbagh, A. M. M. I. Ibrahim, H. P. Luterbacher, 2004. Planktic foraminferal Biostratigraphy, Extinction Patterns and Turnover During the Campanian/ Paleogene K/Pg Boundary in Western Centeral Sinai, Egypt, N. Jb. Geol. Abh., Vol. 234 (1-3), pp. 51 - 120.

Florentine, J. M., R. Maurrasse and G. Sen, 1991. Impacts, Tsunamis, and the Haitian Cretaceous-Tertiary Boundary Layer, Science, Vol. 252, pp. 1690 1693.

Glasby, G. and H. Kunzendorf, 1996. Multiple Factors in the Origin of the Cretaceous/Tertiary Boundary: The Role of Environmental Stress and Deccan Trap Volcanism, Geol. Rundschau, Vol. 85, No. 2, pp. 191 - 210.

Hildebrand, A. and W. Boynton, 1990. Proximal Cretaceous-Tertiary Boundary Impact Deposits in the Caribbean, Science, Vol. 248, No. 4957, pp. 843 - 847. 
Huber, B., M. D. Georgescu, C. Cervato and D. Fils, 2006. CHRONOS online Taxonomic Dictionary for Mesozoic Planktonic oraminifera,www.chronos.org. Kaiho, K. and M. Lamolda, 1999. Catastrophic Extinction of Planktonic Foraminifera at the Cretaceous-Tertiary Boundary Evidenced by Stable Isotopes and Foraminiferal Abundance at Caravaca, Spain, Geology, Vol. 27, No. 4, pp. 355 - 358.

Kassab, I. I. 1974. The Genera Pseudotextularia and Ventilabrella (Foraminiferida) from N. Iraq, Jour. Geol.Soc. Iraq, Vol. 7, pp. 75 - 94.

Kassab, I. I., 1978. Biostratigraphy of the Upper Cretaceous-Lower Tertiary of N. Iraq, Annales des Min. Geol. Tunis, Vol. 28 No. 2, pp. 277 - 325. Actes due VI Africa, Tunis.

Kassab, I. I., 1979. The Genus Globotruncana Cushman, from the Upper Cretaceous of N.Iraq. Vol. 12, pp. 27 - 127.

Mutawali, M. M. 1992. Foraminiferal Biostratigraphy and Sedimentology of the Upper Cretaceous Lower Tertiary from different wells in Khlesiah, Anna and Ramadi, Unpublished PhD thesis, University of Mosul. $268 \mathrm{P}$.

Keller, G., 1988. Extinction, Survivorship and Evolution of Planktic Foraminifera Across the Cretaceous/Tertiary Boundary at El Kef, Tunisia, Marine Micropaleontology, Vol . 13, pp. 239 - 263.

Keller, G., 1989a. Extended Period of Extinctions Across the Cretaceous/Tertiary Poundary in Planktonic Foraminifera of Continental Shelf Sections: Implications for Impact and Volcanism Theories, Geological Society of America Bulletin, Vol.101, pp. 1408 - 1419.

Keller, G., 1989b. Extended Cretaceous/Tertiary Boundary Extinctions and Delayed Population Change in Planktonic Foraminiferal Faunas from Brazos River, Texas, Paleoceanography, Vol. 4, pp. 287 - 332.

Keller, G. 1993. The Cretaceous Tertiary boundary transition in the Anarctic Ocean and its global implication, Marine Micropaleontology, Vol .21, pp. 1 - 45.

Keller, G., E. Barrera, B.Schmitz, E. Mattson, 1993. Gradual Mass Extinction Species Survivorship and Longterm Environmental Changes Across the K/T Boundary in High Latitudes, Geological Society of America Bull. Vol. 105, pp. 979 - 997.

Keller, G., 1996. The Cretaceous-Tertiary Mass Extinction in Planktonic Foraminifera : Biotic Constraints for Catastrophe Theories: In: N.MACLEOD, and.KELLER (Eds). Cretaceous-Tertiary Mass Extinction: Biotic and Environmental Changes. W. W. Norton and Company, New York-London: pp. $49-84$.

Keller, G., 2001, The End-Cretaceous Mass Extinction in the Marine Realm: Year 2000 Assessment: Planetary and Space Science, Vol. 49, pp. 817 - 830. 
Keller, G., T. Adatte, W. Stinnesbeck, D. Stueben and Z. Berner, 2001. Age, Chemo- and Biostratigraphy of Haiti Spherule-rich Deposits:a Multi-Event K-T Scenario. Canadian Journal of Earth Sciences, Vol. 38, pp. 197 - 227.

Keller, G., 2002. Guembelitria-Dominated Late Maastrichtian Planktic Foraminiferal Assemblages Mimic Early Danian in Central Egypt, Marine Micropaleontology, Vol. 47, pp. 71 - 99.

Keller, G., 2004. Low-diversity, Late Maastrichtian and Early Danian Planktic Foraminiferal Assemblages of the Eastern Tethys, Journal of Foraminiferal Research, Vol. 34, No. 1, pp. 49 - 73.

Keller, G., T. Addate, W. Stinnesbeck, V. Luciani, N. Karoui-Yaakoub and D. Zaghbib-Turki, 2002a. Paleoecology of the Cretaceous-Tertiary Mass Extinction in Planktonic Foraminifera, Palaeogeography, Palaeoclimatology, Palaeo-Ecology, Vol. 178, pp. 257 - 297.

Keller, G., T. Adatte, S. J. Burns, and A. A. Tantawy, 2002b. High Stress Paleoenvironment During the Late Maastrichtian to Early Paleocene in Central Egypt, Palaeogeography, Palaeoclimatololgy, Palaeoecology, Vol. 187, pp. $35-60$.

Keller, G., E. Barrera, B. Schmitz, and E. Matsson, 1993. Gradual Mass Extinction, Species Survivorship, and Long Term Environmental Changes Across the Cretaceous-Tertiary Boundary in High Latitudes: Geological Society of America Bulletin, Vol. 105, pp. 979 - 97.

Keller, G., L. Li and N. Macleod, 1995. The Cretaceous/Tertiary Boundary Stratotype Section at El Kef, Tunisia : How Catastrophic was the Mass Extinction ? Palaeogeography, Palaeoclimatology, Palaeoecology, Vol. 119, pp. $221-254$.

Keller,G. and N. MacLeod, (Eds), 1996. Cretaceous-Tertiary Mass Extinctions: Biotic and Environmental Changes.W. W.Norton and Co. (ISBN 0-393-6657-7) .

Keller, G., W. Stinnesbeck and G. Lopiz - Oliva, 1994. Age, Deposition and Biotic Effects of the Cretaceous/Tertiary Boundary Event at Mimbral, NE Mexico. Palaios, Vol. 9, pp. 144 - 157.

Keller, G., W. Stinnesbeck, T. Adatte, and D. Stueben, 2003. Multiple Impacts Across the Cretaceous-Tertiary Boundary, Earth-Science Reviews, Vol. 62, pp. $327-363$.

Li, L. and G. Keller, 1998. Diversification and Extinction in CampanianMaastrichtian Planktic Foraminifera of Northwestern Tunisia. Eclogae Geologicae Helvetiae, Vol. 91, pp. 75 - 102. 
Li, L., G. Keller, W. Stinnesbeck, 1999. The Late Campanian and Maastrichtian in Northwestern Tunisia: Paleoenvironmental Inferences from Lithology, Macrofauna and Benthic Foraminifara. Cretaceous Research, Vol. 20, pp. $231-252$.

Liu, C. and K. P. Olsson, 1994. On the Origin of Danian Normal Perforate Planktonic Foraminifera from Hedbergella. Journal of Foraminiferal Research, Vol. 24, No. 2, pp .61 - 74.

Luciani, V., 1997. Planktonic Foraminiferal Turnover Across the CretaceousTertiary Boundary in the Vajont Valley (Southern Alps, Northern Italy). Cretaceous Research, Vol. 18, pp. 799 - 821.

Luciani, V., 2002. High-Resolution Planktonic Foraminiferal Analysis from the Cretaceous-Tertiary Boundary at AinSettara (Tunisia) : Evidence of an Extended Mass Extinction. Palaeogeography, Palaeoclimatology, Palaeoecology, Vol. 178, pp. 299 -319.

Macleod, N. and G. Keller, 1994. Comparative Biogeographic Analysis of Planktic Foraminiferal Survivorship Across the Cretaceous/Tertiary (K/T) Boundary. Paleobiology, Vol. 20 , pp. 143 - 177.

Mclean, D. M., 1985. Deccan Traps Mantle Degases in the Terminal Cretaceous Marine Extinction, Cretaceous Research, Vol. 6, pp. 235 - 259.

Mclean, D. M., 1991. A Climate Change Mammalian Population Collapse Mechanism. In : E. Kainlauri, et al. (Eds). Energy and Environment. Atlanta, Georgia, Ashrae, pp. 93 - 100.

Mclean, D. M., 1994. Proposed Law of Nature Linking Impacts, Plume Volcanism and Milankovitch Cycles to Terrestrial Vertebrate Mass Extinctions via Greenhouse-Embryodeath Coupling ? In New Developments Regarding the $\mathrm{K} / \mathrm{T}$ Event and Other Catastrophes in Earth History. Houston, Texas, Lunar and Planetary Institute Contribution, Vol. 825, pp. 82 - 83.

Molina, E., Arenillas, I., Arz, J. A., 1998. Mass Extinction in Planktic Foraminifera at the Cretaceous/Tertiary Boundary in Subtropical and Temperate Latitudes. Bulletin de la Sociétégéologique de France, Vol. 169, No. 3, pp. 351 - 363.

Murray, J. W., 1976. A Method Determining Proximity of Marginal Seas to an Ocean.

Marine Geol. Murray, J. W. 1976. A Method Determining Proximity of Marginal Seas to an Ocean. Marine Geol. 22 : pp. 103 - 119. 22 : pp. 103 - 119.

Obaidalla, N. A., 2005. Complete Cretaceous/Paleogene (K/P) Boundary Section at Wadi Nukhul, Southwestern Sinai, Egypt : Inference from Planktic Foraminiferal Biostratigraphy; Revue de Paléobiologie; Vol. 24, No. 1, pp. $201-224$. 
Officer, C. B., 1990. Extinctions, Iridium and Shocked Minerals Associated with the Cretaceous /Tertiary Transition. Journal of Geological Education, Vol. 38, pp. $402-425$.

Officer, C. B. and C. L. Drake, 1985. Terminal Cretaceous Environmental Events. Science, Vol. 277, pp. $1161-1167$.

Officer, C. B., A. Hallam, C. L. Drake and J. D. Devine, 1987. Late Cretaceous and Paroxysmal Cretaceous /Tertiary Extinction. Nature, Vol. 326 ,pp. 143 - 149.

Olsson, R. K., 1997. El Kef Blind test III Results, Marine, Micropaleontol. Vol. 29, pp. $80-84$.

Olsson, R. K., C. Hemleben, W. A. Berggren, and B. T. Huber, (Eds.), 2000. Atlas of Paleocene Planktonic Foraminifera. Smithson. Contrib. Paleobiol., Vol. 85.

Pardo, A., N. Ortiz and G. Keller, 1996. Latest Maastrichtian and CretaceousTertiary Boundary Foraminiferal Turnover and Environmental Changes at Agost, Spain. In :N. Macleod, and G. Keller (Eds). Cretaceous-Tertiary Mass Extinction: Biotic and Environmental Changes. W. W. Norton and Company, New York-London, pp. 139 - 171.

Pardo,A., T. Adatte, G. Keller and H.Oberhansli, 1999. Paleoenvironmental Changes across the Cretaceous-Tertiary boundary of Koshak, Kazakhstan, based on Planktonic Foraminifera and Clay Mineralogy. Palaeogeography, Palaeoclimatology, Palaeoecology, Vol. 154, pp. 247 - 273.

Peryt, D., R. Lahodynsky, R. Rocchia and D. Boclet, 1993. The CretaceousPaleogene Boundary and Planktonic Foraminifera in the Flyschgosau (Eastern Alps, Austria). Palaeogeography, Palaeoclimatology, Palaeoecology, Vol. 104, pp. 239 - 252.

Premoli Sliva, I and C. L. McNulty, 1984. Planktonic Foraminifers And Calpionellids From Gulf of Mexico Sites, Deep Sea Drilling Project LEG 77, In: R.T.Bufler, W. Schlager et al. , Init. Rep. DSDP, Vol. 77, pp. 547 - 721.

Rampino, M. and R. Stothers, 1988. Flood Basalt Volcanism During the Past 250 Million Years, Science, Vol. 241, pp. 663 - 668.

Remane, J., 2003. Chronostratigraphic Correlations: their Importance for the Definition of Geochronologic Units. Palaeogeography, Palaeoclimatology, Palaeoecology. Vol. 196, pp. 7 - 18.

Robaszyniski, F., M. Caron, J. Gonzalez, A. Wonders (eds): 1984. Atlas of Late Cretaceous Globotruncanids, Revue du Micropaleontologie, Vol. 26, No. 3 - 4, pp. 145 - 305.

Schmitz, B., G. Keller and O. Stenvall, 1992. Stable Isotope and Foraminiferal Changes Across the Cretaceous-Tertiary Boundary at Stevns Klint, Denmark: Arguments for Log-Term Oceanic Instability before and after Bolide-Impact Event. Palaeogeography, Palaeoclimatology, Palaeoecology, Vol. 96, pp. 233 - 260. 
Smit, J., 1977. Discovery of a Planktonic Foraminiferal Association between the Abathomphalus Mayaroensis Zone and the Globigerina Eugubina Zone at the Cretaceous/Tertiary Boundary in the Barranco del Gredero (Caravaca, SE Spain):A preliminary Report : koninklijke Nederlandse Akademie Wetenschapen Proceedings, B Vol. 4, pp. 280 - 301.

Smit, J., 1980. Terminal Cretaceous Catastrophe." Nature, Vol. 287, pp. 760 - 775.

Smit, J., 1982. Extinction and Evolution of Planktonic Foraminifera after a Major Impact at the Cretaceous/Tertiay Boundary. Geological Society of America, Special Papers, Vol. 190, pp. 329 - 352.

Smit, J., 1990a. Meteorite Impact, Extinctions and the Cretaceous-Tertiary Boundary, Geologie en Mijnbouw, Vol. 69, pp. 187 - 204.

Smit, J., 1990b. Asteroid Impact, Extinctions and the Cretaceous-Tertiary Boundary. Geologie en Mijnbouw, Vol. 69, pp. 187 - 204.

Smit, J., 1999 . The Global Stratigraphy of the Cretaceous Tertiary Boundary Impact Ejecta, Annual Review of Earth and Planetary Sciences, Vol. 27, pp.75- 113.

Smit, J. and J. Hertogen, 1980. An Extraterrestrial Event at the Cretaceous-Tertiary Boundary, Nature, Vol. 285, pp. 198 - 200.

Smit, J., A. Montanari, N. Swinburne, W. Alvarez, A. R. Hildebrand, S. V. Margolis, P. Claeys, W. Lowrie and F. Asaro, 1992. Tektite-Bearing, DeepWater Clastic Unit at the Cretaceous-Tertiary Boundary in Northeastern Mexico, Geology, Vol. 20, pp. 99 - 103.

Tantawy, A. A., G. Keller, T. Adatte, W. Stinnesbeck, A. Kassab, and P. Schulte, 2001. Maastrichtian to Paleocene (Dakhla Formation) Depositional Environment of the Western Desert in Egypt: Sedimentology, Mineralogy and Integrated Micro- and Macrofossil Biostratigraphies. Cretaceous Research,Vol. 22, pp. 795-827.

Tourmarkine, M. and H. Luterbacher, 1985., Paleocene and Eocene Planktic Foraminifera.In Bolli, H. M., Saunders, J. B., and Perch-Nielsen, K. (Eds.), Plankton Stratigraphy: Cambridge (Cambridge Univ. Press), pp. 87 - 154. 